\title{
Pengaruh Strategi Pemasaran Terhadap Minat Nasabah Memilih Produk Tabungan Ib Baitullah Hasannah Pada Bank BNI Syariah Cabang Palu
}

\author{
Nunung Dini Apriliani ${ }^{1 *}$,Sofyan Bachmid ${ }^{2}$, Saifullah Saifullah ${ }^{3}$ \\ ${ }^{1}$ Jurusan Perbankan, Fakultas Ekonomi dan Bisnis Islam, IAIN Palu \\ ${ }^{2}$ Jurusan Perbankan, Fakultas Ekonomi dan Bisnis Islam, IAIN Palu \\ ${ }^{3}$ Jurusan Perbankan, Fakultas Ekonomi dan Bisnis Islam, IAIN Palu
}

ABSTRAK

INFORMASI

ARTIKEL

Tulisan ini membahas pengaruh strategi pemasaran terhadap minat nasabah dalam memnlilih produk tabungan Ib Baitullah

Katakunci:

Hasanah pada Bank BNI Syariah Palu. Penelitian ini dilakukan dengan menggunakan metode kuantitatif. Jumlah responden penelitian ini adalah 99 orang yang merupakan nasabah ban BNI Syariah Palu. Sampel diambil secara acak dan kemudian dibagikan kuesiner dengan skala Likert 5. Hasil penelitian menunjukkan bahwa produk, promosi dan harga berpengaruh simultan dan signifikan terhadapminat nasabah memilih produk tabungan iB Baitullah Hasanah pada Bank BNI Syariah cabang Palu. Hal ini dapat dilihat dari penelitian yang telah diteliti oleh peneliti menunjukkan bahwa dari hasil uji $\mathrm{F}$ diperoleh nilai $F_{\text {hitung }}>\mathrm{F}_{\text {tabel }}$ yaitu 8.566> $\mathrm{F}_{\text {tabel }}$ 3.09dengan nilai probabilitas sebesar 0.000 berarti lebih kecil dari 0.05 maka $\mathrm{H} 4$ diterima. Yang artinya produk, promosi dam harga berpengaruh secara simultan dan signifikanterhadap minat nasabah memilih produk tabungan iB Baitullah Hasanah pada Bank BNI Syariah cabang Palu 


\section{PENDAHULUAN}

Bank diartikan sebagai modal yang ditransfer dari pemilik yang tidak dapat menggunakan dana tersebut menjadi keuntungan (profitable) kepada pihak pihak yang dapat menggunakan sehingga produktif bagi masyarakat banyak. ${ }^{1}$ perbankan adalah segala sesuatu yang menyangkut tentang bank syariah dan unit usaha syariah,mencakup kelembagaan,kegiatan usahanya $^{2}$. Adanya perbankan syariah dilatar belakangi oleh keinginan umat Islam untuk menghindari riba dalam kegiatan muammalahnya dan adanya keinginan umat Islam untuk memperoleh kesejahteraan lahir batin melalui kegiatan muammalah yang sesuai dengan perintah agama. ${ }^{3}$

Kegiatan perekonomian di Indonesia saat ini khususnya pada sektor perbankan telah berkembang pesat. Hal ini dibuktikan dengan adanya persaingan yang begitu ketat. Oleh karena itu dibutuhkan kegiatan pemasaran untuk menghadapi pesaing yang dari waktu kewaktu semakin meningkat. Para pesaing akan semakin gencar melakukan usaha pemasaran dalam rangka

\footnotetext{
${ }^{1}$ Ahmad Dahlan, Bank Syariah Teoritik, Praktik, Kritikcet II (Jakarta: Teras, 2012), hal. 98.

${ }^{2}$ Undang-Undang Nomor 21 Tahun 2008 tentang Perbankan Syariah.

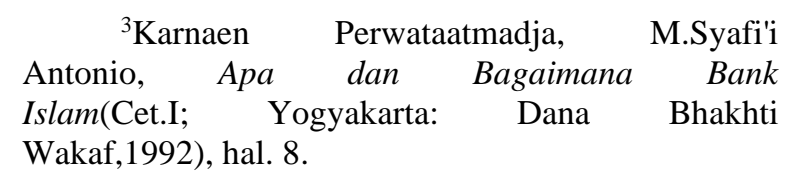

memasarkan produknya, karena dari aktivitas pemasaran tersebut diharapkan bank bisa memperoleh keuntungan.

Kegiatan pemasaran selalu ada dalam setiap usaha,baik usaha yang berorientasi profit maupun usaha-usaha sosial. Hanya saja sebagai pelaku pemasaran dilakukan dalam rangka memenuhi kebutuhan dan keinginan masyarakat akan suatu produk atau jasa. Pemasaran akan menjadi sangat penting dengan semakin meningkatnya pengetahuan masyarakat. Dalam meningkatkan suatu pemasaran perusahaan memiliki beberapa tujuan yang hendak dicapai baik tujuan jangka pendek maupun tujuan jangka panjang. Dalam jangka pendek biasanya untuk merebut hati konsumen terutama untuk produk yang baru di luncurkan, sedangkan dalam jangka panjang dilakukan untuk mempertahankan produkproduk yang sudah ada agar tetap eksis ${ }^{4}$.

Menurut William J. Stantom sebagaimana yang dikutip oleh ikatan bankir Indonesia:

Pemasaran adalah suatu sistem dalam kegiatan bisnis yang ditujukan untuk merencakan, menentukan harga, mempromosikan serta mendistribusikan barang dan jasa yang memuaskan kebutuhan exiting customer dan patential customer ${ }^{5}$.

${ }^{4}$ Kasmir, Pemasaran Bank, (cet II; Jakarta: Kencana, 2005), hal. 59-60

${ }^{5}$ Ikatan Bankir Indonesia,Strategi Bisnis Bank Syariah, (edisi cet I; Jakarta: PT. Gramedia Pustaka Utama, 2015), hal. 115-116. 
Mendukung suatu kegiatan pemasaran harus diperlukan adanya strategi karena strategi pemasaran mencakup setiap usaha untuk mencakup kesuaian antara perusahaan dan lingkungannya dalam rangka mencari pemecahan atas masalah penentuan dua pertimbangan pokok, yaitu,bisnis yang akan digeluti, dan bisnis yang dipilih tersebut dapat dijalankan dengan sukses dalam lingkungan yang kompetitif atas dasar perspektif produk, harga, promosi, dan distribusi (bauran pemasaran) untuk melayani pasar sasaran.

Produk merupakan sesuatu yang bisa ditawarkan pada suatu pasar sasaran guna mendapatkan perhatian untuk dimiliki, digunakan, dikonsumsi yang dapat memuaskan kebutuhan. Selain produk, harga juga dapat mempengaruhi, harga merupakan sejumlah uang yang dibebankan atas suatu produk jasa atau jumlah dari nilai yang ditukar konsumen atas manfaat-manfaat karena memiliki atau menggunakan produk atau jasa terebut. Dan promosi yang merupakan sarana komunikasi antara konsumen dan produsen untuk memperkenalkan warna, bentuk, jenis barang,serta kualitas dari suatu barang guna memenuhi keinginanan dan kebutuhan konsumen. ${ }^{6}$

${ }^{6}$ Philip Kotler, Marketing Management jilid I, terj. Benyamin Molan,Manajemen Pemasaran, (Jakarta:Indeks Gramedia,2005)hal 19
Produk tabungan iB Baitullah Hasanahmerupakan produk tabungan haji yang dikelola secara syariah sebagai sarana pembayaran Haji untuk mendapatkan kepastian porsi berangkat menunaikan ibadah Haji. Ibadah haji merupakan rukun Islam yang kelima, diwajibkan bagi umat Islam yang mampu untuk mengadakan perjalanan ke Baitullah. Negara Indonesia yang mayoritas beragama Islam membawa pengaruh besar terhadap banyaknya jumlah jama'ah haji yang siap diberangkatkan ke Baitullah. Setiap tahunnya jumlah jamaah haji yang mendaftar selalu melebihi kuota pemberangkatan. Hal itu didukung dengan adanya kesepakatan dari Kementrian Agama yang telah menetapkan 17 bank untuk mengelola setoran BPIH (Biaya Penyelenggaraan Ibadah Haji) dan 6 bank syariah sebagai bank penerima setoran ${ }^{7}$.

Persoalan yang mendasar mengenai ibadah haji adalah masalahpendanaan, banyak masyarakat yang ingin menunaikan ibadah haji namun biaya yang tersedia tidak mencukupi untuk pembayaran pembiayaan ibadah haji. Dalam kegiatan ini Dewan Syariah Nasional memberikan kesempatan kepada Lembaga Keuangan Syariah (LKS) untuk merespon kebutuhan masyarakat dalam berbagai produknya termasuk

${ }^{7}$ kemenagtakenkesepakatandenganbanksyariah penerimadanahaji,https://m.detik.com/finance/monete $\underline{\text { r/2451031. diakses pada 15 Maret } 2019 .}$ 
pengurusan tentang ibadah haji dalam hal ini adalah tabungan haji.

Untuk menanggapi persoalan diatas Bank BNI Syariah senantiasa menyediakan produk tabungan iB Hasanah dan layanan yang sesuai dengan kebutuhan dan harapan masyarakat mengingat banyaknya masyarakat mempunyai keinginan untuk melaksanakan ibadah haji.

\section{TINJAUAN PUSTAKA}

\subsection{Pengertian Strategi Pemasaran}

Seseorang yang terlibat dalam bisnis, khususnya pemasaran tentunya akan berhadapan dengan persaingan yang amat dinamis. Perubahan lingkungan yang dinamis ini seringkali diantisipasi dengan baik oleh para pelaku bisnis, sehingga banyak sekali perusahaan yang punya nama besar berjatuhan karena gagal mengantisipasinya.

Tokoh yang memiliki andil besar dalam mempopulerkan dan memperkuat konsepkonsep untuk strategi bisnis baru muncul mulai era 1960-an, yaitu Kemeth andrews, Igor Ansoff, dan Alferd Chandler, Jr. Ketiga nama tersebu terkenal sebagai permarkasa yang luar biasa didalam dunia strategi bisnis. Strategi telah di definisikan dalam beberapa cara oleh banyak penulis, seperti $:^{8}$

${ }^{8}$ Thamrin Abdullah, Manajemen Pemasaran (cet II(Jakarta : PT RajaGrafindoPersada, 2003) a. Strategi adalah penetapan tujuan dasar jangka panjang dan sasaran perusahaan dan menetapkan serangkain tindakan serta alokasi sumber daya yang penting untuk melaksanakan sasaran.

b. Strategi adalah sekumpulan pilihan dasar atau kritis melalui tujuan dan cara dari bisnis.

c. Strategi adalah arah dan cakupan organisasi secara ideal untuk jangka yang lebih panjang, yang menyesuaikan sumber dayanya dengan lingkungan yangberubah, dan secara khusus, dengan pasarnya dengan pelanggan dan kliennya untuk memenuhi harapan stakeholder.

d. Amstrong dalam kumpulan buku The Art of HRD mengatakan bahwa setidaknya ada tiga pengertian strategi. Pertama, strategi merupakan deklarasi maksud yang mendefiniskan cara untuk mencapai tujuan dan memperhatikan dengan sungguh-sungguh alokasi sumber daya perusahaan yang penting untuk jangka panjang dan mencocokan sumber daya dan kapasitas dan lingkungan eksternal. Kedua, strategi merupakan perspektif dimana isu kritis atau faktor keberhasilan dapat dibicarakan, serta keptusan strategis bertujuan untuk membuat dampak yang besar serta jangka panjang kepada pelaku dan keberhasilan organisasi. Ketiga, strategi pada dasarnya mengenai penetapan tujuan (tujuan strategi) dan 
pengalokasian atau menyesuaikan sumber daya dengan peluang (strategi berbasis sumber daya) sehingga dapat mencapai kesesuaian strategis anatara tujuan strategi dan basis sumber dayanya.

Berdasarkan keseluruhan definisi diatas, maka strategi dapat didefinisikan sebagai sekumpulan nilai kritis untuk perencanaan dan penerapan serangkaian rencana tindakan dan alokasi sumber daya yang penting dalam mencapai tujuan dasar dasar dan sasaran,dengan memperhatikan keunggulan kompetitif,komperatif,dan sinergis yang ideal berkelanjutan sebagai arah cakupan dan perspektif berjangka panjang keseluruhan yang ideal dari individu atau organisasi. ${ }^{9}$

Pemasaran menjadi salah satu bidang fungsional yang sangat penting dalam suatu organisai bisnis sebagaipenunjang utama bagi kelangsungan hidup suatu dunia usaha. Pemahaman pemasaran bagi pihak peemasaran sangat penting dalam rangka pengenalan kebutuhan dan keinginan nasabah, penetuan pasar sasaran mana yang dapat dilayani sebaik baiknya oleh bank serta merancang produk jasa dan program yang tepat untuk melayani pasar tersebut.

Besarya peranan sistem pemasaran mengahruskan setiap dunia usaha lebih mencermati studi tentang pemasaran. Beberapa ahli dibidang pemasaran. Salah

${ }^{9} I b i d$, hal 15 satu cara yaitu dengan memahami pemasaran itu sendiri seperti apa dan bagaimana. Sehingga tidak hanya menghasilakn keuntungan dari pihak bank, tetapi juga kepuasan nasabah dalam mengonsumsi produk dari bank itu sendiri.

Dalam memaparkan masalah pemasaran tidak lepas dari pengertian pemasaran. Beberapa ahli dibidang pemasaran memberikan pengertian dan definisi yang berbeda tentang pemasaran sesuai dengan sudut pandang bagaimana mereka melihatnya, namun pada dasarnya mempunyai tujuan dan maksud yang sama.

Philip Kotler mengartikan pemasaran sebagai sebuah proses dimana individu dan kelompok memperoleh apa yang mereka butuhkan dan inginkan dengan menciptakan,menawarkan dan secara bebas menentukan barang dan jasa yang bernilai dengan orang lain ${ }^{10}$.

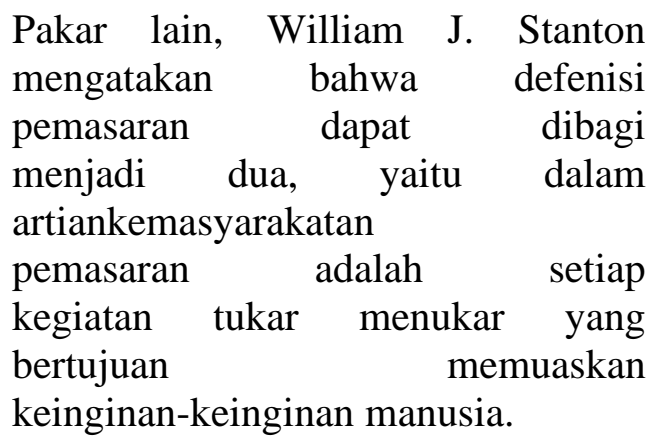

Dalam arti bisnis pemasaran adalah sebuah sistem dari kegiatan bisnis yang

${ }^{10}$ Philip Kotler,Marketing Management,terj. Bob Sabran Manajemen Pemasaran, (Edisi XIII, Jakarta: Erlangga,2009), hal.5 
dirancang untuk merencanakan, memberikan harga, mempromosikan dan mendistribusikan jasa serta barang-barang pemuas keinginan pasar. $^{11}$

Menurut Freddy Rangkuti, pemasaran adalah suatu proses kegiatan yang dipengaruhi pleh berbagai faktor sosial,budaya, politik, ekonomi dan manajerial. Akibat dari pengaruh berbagai faktor tersebut adalah masing masing individu maupun kelompok mendapatkan kebutuhan dan keinginan dengan menciptakan, menawarkan dan menukarkan produk yang memiliki nilai komoditas. ${ }^{12} \mathrm{Di}$ sisi lain Asosiasi pemasaran di Amerika berpendapat bahwa pemasaran itu adalah proses perencanaan dan pelaksanaan pemikiran, menetapkan harga, promosi dan penyaluran gagasan individu dan organisasi. $^{13}$

Indriyo Gitosudarmo mengartikan pemasaran sebagai suatu kegiatan yang mengusahakan agar suatu produk yang dipasarkan itu dapat diterima dan di senangi oleh pasar. ${ }^{14}$

\footnotetext{
${ }^{11}$ William J.Stanton,Principles Of Marketing, terj. Imam NurmawanPrinsip Pemasaran, (Edisi VII, Jakarta:Erlangga,1996), hal.21
}

${ }^{12}$ Freddy Rangkuti, Analisis swot: Tekhnik Membedah Kasus Bisnis Cet IV(Jakarta: Gramedia Pustaka Umum, 2006) hal.48

${ }^{13}$ Philip Kotler, Marketing Management, terj. Bob Sabran Manajemen Pemasaran(Edisi XI, jilid I, Jakarta:Indeks,2005) hal.10

${ }^{14}$ Ibid, hal 1
Sedangkan menurut Payne, pemasaran merupakan suatu proses mempersiapkan,memahami,menstimulasi, dan memenuhi kebutuhan pasar sararanyang di pilih secara khusus menyalurkan sumbersumber sebuah organisasi untuk memenuhi kebutuhan-kebutuhan tersebut. ${ }^{15}$

Pemasaran tidak hanya dapat dilihat dalam ruang lingkup umum, akan tetapi bisa dilihat dari sudut pandang syariah. Pemasaran dari perspektif syariah adalah segala aktivitas yang dijalankan dalam kegiatan bisnis berbentuk kegiatan penciptaan nilai yang memungkinkan siapapun yang melakukannya bertumbuh dan menyalahgunakan kemanfaatannya yang dilandasi atas kejujuran, keadilan, keterbukaan,dan keikhlasan sesuai dengan proses yang berprinsip pada akad muammalah islami atau perjanjian transaksi bisnis dalam Islam. ${ }^{16}$

\subsection{Bauran pemasaran}

Bauran pemasaran ( Marketing Mix) Merupakan strategi kombinasi yang di lakukan oleh berbagai perusahaan dalam bidang pemasaran. Kombinasi yang terdapat dalam komponen markening mix harus

\footnotetext{
${ }^{15}$ Payne Adrian, The Essence of Serfice Marketing,terj. Fandi Tjiptono servis marketing pemasaran jasa, (cet I Yogyakarta: Andi offset, 1993) hal27.

${ }^{16}$ Abdullah Amrin, strategi pemasaran asuransi syariah, ( cet 1Jakarta: Grasindo,2007), hal 1
} 
dilakukan secara terpadu. Artinya, pelaksanaan dan penerapan komponen ini harus dilakukan dengan komponen dengan komponen lainnya. Karena antara komponen dengan komponen lainnya saling berkaitan erat guna mencapai tujuan perusahaan dan tidak efektif jika dijalankan sendiri-sendiri.

Penggunaan bauran pemasaran (marketing mix) dalam dunia perbankan di lakukan dengan menggunakan konsepkonsep yang sesuai dengan kebutuhan bank. Dalam praktiknya konsep bauran pemasaran terdiri dari bauran pemasaran untuk produk dan jasa. Khusus untuk produk yang berbentuk barang dan jasa di perlakukan konsep yang sedikit berbeda dengan produk barang.

\section{Product (produk)}

Produk adalah suatu yang bisa ditawarkan pada suatu pasar sasaran guna untuk mendapatkan perhatian untuk dimiliki, digunakan, di konsumsi yang dapat memuaskan kebutuhan. Menurut Philip Kotler produk adalah apa yang ditawarkan kepasar untuk diperlihatkan, diperoleh, digunakan atau dikonsumsi yang dapat memenuhi keinginan atau kebutuhan. ${ }^{17}$

Jadi dapat disimpulkan bahwa produk merupakan objek dalam pemasaran. Tanpa produk pemasaran tidak akan berjalan karena

${ }^{17}$ Philip Kotler,Marketing Management, terj. Bob Sabran Manajemen Pemasaran,(jilid 1Edisi 12; Jakarta: Indeks Gramedia,2005) hal 19 produk merupakan jumlah total kepuasan serta spritual yang diperoleh dari pembelian atau penggunannya. Untuk itu perusahaan harus mampu mengetahui kebutuhan konsumen dengan meneliti pasar agar dapat menyesuaikan diri dalam menciptaka produk sesuai dengan kebutuhan konsumen.

\section{Price (Harga)}

Harga merupakan sejumlah uang yang dibebankan atas suatu produk jasa atau jumlah dari nilai yang ditukar konsumen atas manfaat-manfaat karena memiliki atau menggunakan produk atau jasa tersebut.

Harga dapat diungkapkan dengan beberapa istilah, misalnya tarif, sewa, bunga, premium, komisi, upah, gaji dan sebagainya.Dari sudut pandang pemasaran, harga merupakan satuan moneter atau ukuran lainnya (termasuk barang atau jasa) yang ditukarkan agar memperoleh hak kepemilikan atau penggunaan suatu barang dan jasa.Harga merupakan titik kritis dalam bauran pemasaran karena harga menentukan pendapatan dari suatu usaha/bisnis. Keputusan penentuan harga juga sangat signifikan didalam penentuan nilai atau manfaat yang dapat diberikan kepada pelanggan dan memainkan peranan penting dalam gambaran kualitas jasa. ${ }^{18}$

\footnotetext{
${ }^{18}$ Meinarti Puspaningtyas," Analisis Strategi Pemasaran Jasa". Jurnal Dinamika com. Vol. 2No. 1. Hal 61.
} 
Kesimpulannya harga merupakan sejumlah uang yang dibebankan atas suatu produk jasa atau jumlah dari nilai yang ditukar konsumen atas manfaat-manfaat karena memiliki atau menggunkaan produk atau jasa tersebut.

\section{Promotion (promosi)}

Promosi merupakan sarana komunikasi antara konsumen dan produsen untuk memperkenalkan warna, bentuk, jenis barang, harga serta kualiatas dari suatu barang guna memenuhi keinginan dan kebutuhan konsumen.

Promosi adalah aktivitas yang menyampaikan manfaat produk dan membujuk pelanggan membelinya. ${ }^{19}$ Kegiatan promosi merupakan komponen yang dipahami untuk memberitahukan dan mempengaruhi pasar bagi produk perusahaan, sehingga pasar dapat mengetahui tentang produk yang diproduksi oleh perusahaan tersebut.Tanpa promosi nasabah tidak dapat mengenal asuransi. Oleh karena itu, promosi merupakan sarana yang paling ampuh untuk menarik dan mepertahankan nasabahnya.Salah satu tujuan promosi adalah menginformasikan segala jenis produk yang ditawarkan dan berusaha menarik calon nasabah yang baru.

\footnotetext{
${ }^{19}$ Philip Kotler, Amstrong,Principles Of Marketing, terj. Bob Sabran Prinsip-Prinsip Pemasaran, (Edisi 12 jilid 1; Jakarta:Erlangga,2008),Hal 9
}

Adapun kegiatannya adalah: Periklanan, personal selling, promosi penjualan dan publisitas. ${ }^{20}$ Promosi penjualan adalah suatu tindakan perusahaan untuk menjajakan produk yang dipasarkan sedemikian rupa sehingga konsumen akan mudah melihatnya dan bahkan dengan cara penempatan dan peraturan tertentu maka prodk tersebut akan menarik perhatian konsumen. ${ }^{21}$

Dari definisi diatas dapat disimpulkan, Promosi ialah suatu kegiatan upaya membujuk atau mempengaruhi konsumen dalam pembelian atau penggunaan jasa melalui arus informasi.

4. $\quad$ Place (Tempat atau Distribusi)

Tempat atau distribusi adalah tempat dimana diperjualbelikannyaproduk perbankan dan pusat pengendalian perbankan. Distribusi juga merupakan kegiatan ekonomi yang menjembatani kegiatan produksi dan konsumsi, berkat distribusi, barang atau jasa dapat sampai ketangan konsumen. Dalam sektor jasa, distribusi didefenisikan sebagai sarana yang dapat meningkatkan keberadaan atau kenikmatan suatu jasa yang menambah pendapatan dari penggunannya, baik dengan mempertahankan pemakai yang ada, meningkatkan nilai kegunaannya diantara

\footnotetext{
${ }^{20} \mathrm{Ibid}$, h. 246

${ }^{21}$ Agus Hermawan, Komunikasi Pemasaran(cet 5; Jakarta: Erlangga, 2012), h. 160
} 
pemakai yang ada ataupun menarik pemakai yang baru.

$$
\text { 5. People (orang) }
$$

People berarti orang yang melayani ataupun yang merencanakan pelayanan terhadap konsumen. Karena sebagian besar jasa dilayani oleh orang maka orang tersebut diseleksi, dilatih, dimotivasi sehingga dapat memberikan kepuasan terhadap pelanggan.Orang atau karyawan merupakan unsur marketing mix (bauran pemasaran)memiliki peran penting karena terlibat langsung dalam kegiatan penyampaian produk dengan konsumen ${ }^{22}$.

\section{Physical evidence (Bukti Fisik)}

Physical evidence / Bukti Fisik merupakan lingkungan, warna, tata letak dan fasilitas tambahan. Ini terkait dengan tampilan sebuah produk/jasa yang ditawarkan terkait dengan packaging yang disajikan untuk menarik konsumen.proses ini adalah salah satu elemen inti yang ada di 9 core elemens of marketing, namun melihat korelasi yang penting maka elemen ini ditarik masuk menjadi salah satu bagian marketing mix. Beberapa indikator yang diperlukan adalah prosedur, kebijakan, mekanisasi,arah aktifitas dan sebagainya ${ }^{23}$

${ }^{22}$ Valdy Ronald Wowor, Bauran Pemasaran Jasa Pengaruhnya Terhadap Kepuasan Konsumen Pengguna Avanza PT.Hasjrat Abadi Manado” Jurnal Manajemen Vol.1 No 4 (Desember,2017) hal 23

${ }^{23}$ Kotler dan Armstrong,Marketing Management ,terj. Bob SabranManajemen Pemasaran,(jilid kedua; Jakarta: Prenhalindo,1998)

\section{Process}

Proses adalah menciptakan dan memberikan jasa kepada konsume, merupakan faktor utama dalam bauran pemasaran pada ekonomi manajemen jasa, pelanggan akan memandang sistem pelayanan jasa. Semua kegiatan pekerjaan adalah bagian dari suau proses. Proses ini dapat meliputi berbagai mekanisme yang ada, seperti adanya mekanisme pelayanan, prosedur, jadwal kegiatan, serta rutinitas. ${ }^{24}$

Menurut Philip Kotler, proses adalah mencakup bagaimana cara perusahaan melayani tiap permintaan konsumennya, mulai dari konsumen tersebut memesan (order) hingga akhirnya konsumen mendapatkan apa yang diinginkan. ${ }^{25}$

\subsection{Strategi Pemasaran Bank Syariah}

Strategi pemasaran adalah serangkaian tujuan atau sasaran, kebijakan dan aturan yang memberi arah kepada usahausaha pemasaran perusahaan dari waktu ke waktu, pada masing-masing tingkatan dan acuan serta alokasinya, terutama sebagai tanggapan perusahaan dalam mengahadapi lingkungan dan keadaan pesaing yang selalu berubah. ${ }^{26}{ }^{27}$

\footnotetext{
${ }^{24}$ Payne A,The Essence Of ServiceOf Marketing,terj. Fandi TjiptonoServiceMarketing Pemasaran Jasa, (cet II Yogyakarta, 2006) hal 26

${ }^{25}$ Philip Kotler,Marketing Managementterj. Bob SabranManajemen Pemasaran, ( Cet III Jakarta:PT Prenhalindo,2008) hal 10

${ }^{26}$ Sofjan Assauri, Manajemen Pemasaran (cet I; Jakarta PT.Raja Grafindo Persada,2007) hal 168 27 Nurdin, N. (2016). The Roles of Information Technology in Islamic Bank Knowledge
} 
Strategi pemasaran merupakan bagian integral dari strategi bisnis yang memberikan arah pada semua fungsi manajemen suatu organisasi bisnis. Dengan adanya strategi pemasaran, maka implementasi program dalam mencapai tujuan organisasi dapat dilakukan secara aktif, sadar dan rasional tentang bagaimana suatu produk mencapai tujuannya dalam lingkungan bisnis.

Dalam pemasaran juga terdapat beberapa konsep yang digunakan diantarannya menurut Thamrin Abdullah, "konsep pemasaran adalah suatu proses sosial dan menejerial di mana individu dan kelompok mendapatkan kebutuhan dan 5. keinginan mereka dengan menciptakan, menawarkan dan bertukar sesuatu yang bernilai satu sama lain. ${ }^{28}$

Sedangkan konsep pemasaran adalah kumpulan lembaga-lembaga yang melakukan tugas pemasaran, barang dan jasa, ide, oang dan faktor lingkungan yang saling memberikan pengaruh dan membentuk serta mempengaruhi hubungan perusahaan dengan pasarnya. ${ }^{29}$

\section{a. Fungsi Strategi Pemasaran}

Management: A study of Two Syariah Banks in Palu. Hunafa: Jurnal Studia Islamika, 13(2), 181-217. doi: https://doi.org/10.24239/jsi.v13i2.444.181-217

\footnotetext{
${ }^{28}$ Thamrin Abdullah, Manajemen Pemasaran (cet III; Jakarta PT.Raja Grafindo Persada,2013) hal 14

${ }^{29}$ M.Mursid, Manajemen Pemasaran (cet III; Jakarta: Bumi Aksara,2014) hal 8
}

1. Sebagai respon organisasi untu menanggapi dan menyesuaikan diri terhadap lingkungan sepanjang siklus bisnis.

2. Sebagai upaya untuk membedakan dirinya dari pesaing dengan menggunakan kekuatan korporat untuk memenuhi kebutuhan nasabah atau pelanggan yang lebih dalam lingkungan tertentu.

3. Sebagai kunci keberhasilan dalam menghadapi perubahan lingkungan bisnis memberikan kesatuan arah bagi semua mitra internal suatu bank perusahaan.

4. Sebagai pedoman dalam mengalokasikan sumber daya dan usaha.

5. Sebagai alat fundamental untuk mencapai tujuan suatu bank atau perusaan dengan mengembangkan keunggulan bersaing yang berkesinambungan dalam melayani pasar sasaran.

a. Tujuan pemasaran bank Secara umum tujuan pemasaran bank terbagi atas 4 bagian diantaranya adalah: ${ }^{30}$

1. Memaksimalkan konsumen atau dengan kata lain memudahkan dan merangsang konsumi, sehingga dapat menarik nasabah untuk membeli produk yang ditawarkan bank secara berulang ulang.

2. Memaksimumkan keputusan pelanggan melalui berbagai pelayanan yang diinginkan nasabah. Nasabah yang puas

\footnotetext{
${ }^{30}$ Ibid, hal. 12
} 
akan menjadi ujung tombak pemasaran selanjutkannya, karena pemasaran ini akan ditularkan kepada nasabah lainnya melalui cerita.

3. Memaksimumkan pilihan (ragam produk) dalam arti bank menyediakan berbagai jenis produk bank sehingga nasabah memiliki beragam pilihan pula.

4. Memaksimumkan mutu hidup dengan memberikan berbagai kemudahan kepada nasabah dan menciptakan iklim yang efisien.

b. karakteristik Marketing Syariah

Konsep pemasaran syariah ini sendiri saat ini baru berkembang seiring berkembangnya ekonomi syariah. Beberapa perusahaan dan bank khususnya yang berbasis syariah telah menerapkan konsep ini dan mendapatkan hasil yang positif. Kedepannya diprediksikan marketing syariah ini akan terus berkembang dan akan dipercaya masyarakat karena nilai-nilainya yang sesuai dengan apa yang dibutuhkan masyarakat, yaitu kejujuran. Secara umum pemasaran syariah adalah sebuah disiplin bisnis strategi yang mengarahkan proses penciptaan, penawaran dan perubahasn value dari inisiator kepada stakeholdernya yang dalam keseluruhan prosesnya sesuai dengan akad dan prinsip-prinsip muamalah dalam Islam. Artinya dalam pemasaran syariah seluruh proses baik proses penciptaan,proses penawaran, maupun proses perubahan nilai tidak boleh ada yang bertentangan dengan prinsip-prinsip syariat.

\section{Minat Nasabah}

Minat sebagai aspek kejiwaan bukan hanya mewarnai prilaku seseorang. untuk melakukan aktivitas yang menyebabkan tertarik kepada sesuatu. Minat adalah ketertariakan terhadap sesuatu yang muncul dari diri seseorng, yang mana hal ini juga sesuai pada teori perilaku konsumen yang berarti suatu kegiatan individu yang secara langsung terlibat dalam mendapatkan dan mempengaruhi barang-barang atau jasa termasuk didalamnya suatu proses pengembalian keputusan pada persiapan dan penentuan kegiatan-kegiatan tersebut. ${ }^{31}$

Menurut Kamuk minat nasabah yaitu pengaruh eksternal, kesadaran akan kebutuhan, pengenalan produk dan evaluasi alternatif adalah hal yang dapat menimbulkan minat beli konsumen. Pengaruh eksternal ini terdiri dari usaha pemasaran dan faktor sosial budaya. ${ }^{32}$

Minat berarti ketertarikan seseorang terhadap suatu barang atau jasa untuk dimiliki maupun dikonsumsi. Minat merupakan kecenderungan konsumen untuk membeli suatu merek atau mengambil tidakan yang berhubungan dengan

${ }^{31}$ Danang Suntoyo, Teori, Kuesioner, dan analisis Data Untuk Pemasaran dan prilaku Konsumen(cet I Yogyakarta: Ghara Ilmu, 2013), h.66.

${ }^{32}$ Ratih Hurriyati,Bauran dan Loyalitas Konsumen, (cet III Bandung: Alfabeta,2010)hal 58 
pembelian yang diukur dengan tingkat kemungkinan konsumen melakukan pembelian. $^{33}$

\subsection{Kerangka Pemikiran}

Dalam penelitian ini dapat dibuat suatu kerangka pemikiran yang dapat menjadi landasan dalam penelitian ini yang pada akhirnya dapat diketahui variabel mana yang paling dominan dalam mempengaruhi keputusan nasabah dalam memilih produk perbankan.Variabel-variabel penelitian yang digunakan dalam penelitian ini adalah keputusan minat nasabah sebagai variabel dependen. Sedangakan kinerja marketing,keunggulan produk dan kualitas informasi sebagai variabel independen.Kerangka pemikiran dalam penelitian ini secara sistematis dapat digambarkan sebagai berikut:

Gambar 1. Kerangka Pemikiran

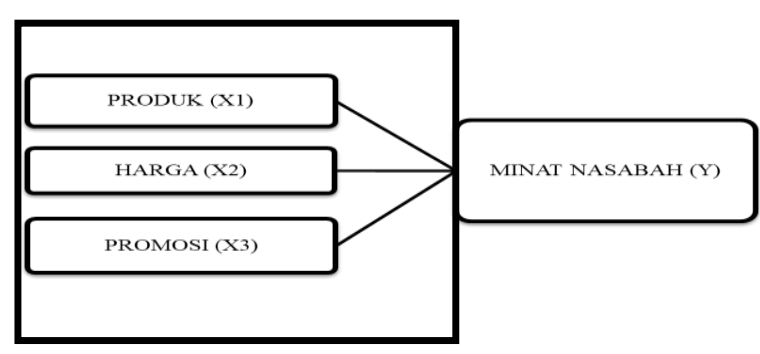

Keterangan :

$$
\text { : pengaruh secara simultan }
$$

\footnotetext{
${ }^{33}$ Roni Andespa,'Faktor-faktor Yang Mempengaruhi Minat Nasabah Dalam Menabung DibankSyariah", Jurnal Lembaga Keuangan Perbankan, Vol. 2 No. h. 44.
}

: pengaruh secara parsial

\subsection{Hipotesis}

Hipotesis berasal dari kata hypo yang berarti di bawah dan thesa yang berarti kebenaran. Hipotesis dapat didefinisikan sebagai jawaban sementara yang kebenarannya masih harus diuji atau rangkuman simpulan teoretis yang diperoleh dari tinjauan pustaka. Hipotesis juga merupakan proposisi yang akan diuji keberlakuannya atau merupakan suatu jawaban sementara atas pertanyaan penelitian. ${ }^{34}$ Berdasarkan latar belakang dan masalah yang dikemukakan, maka hipotesis yang digunakan adalah sebagai berikut :

1. Di duga terdapat pengaruh positif dan signifikan antara strategi produk dengan minat nasabah.

2. Di duga terdapat pengaruh positif dan signifikan antara strategi harga dengan minat nasabah.

3. Di duga terdapat pengaruh positif dan signifikan antara strategi promosi dengan minat nasabah.

4. Di duga terdapat pengaruh positif dan signifikan antara starategi produk, harga dan promosi dengan minat nasabah.

\footnotetext{
${ }^{34}$ Nanang Martono, Metode Penelitan Kuantitatif Analisis Isi dan Analisis Data Sekundser, (Cet. IV; Jakarta: PT. Grafindo Persada, 2016), 67.
} 


\section{METHODOLOGY}

Dalam melakukan penelitian ini penulis menggunakan penelitian kuantitatif.Metode penelitian kuantitatif dapat diartikan sebagai metode penelitian yang berlandaskan pada filsafat positivisme, digunakan untuk meneliti pada populasi atau sampel tertentu, teknik pengambilan sampel pada umumnya dilakukan secara random, pengumpulan data menggunakan instrumen penelitian, analisis data bersifat/statistik dengan tujuan untuk menguji hipotesis yang telah ditetapkan. ${ }^{35}$

Filsafat positifisme memandang realitas/gejalah/fenomena itu dapat diklasifikasikan, relatif tetap, konkrit, teramati, terukur, dan hubungan gejalah bersifat sebab akibat ${ }^{36}$. Penelitian pada umumnya dilakukan pada populasi atau sampel tertentu yang representatif. ${ }^{37}$

Lokasi penelitian di Bank BNI Syariah cabang Palu yang terletak di Jalan Moh.Yamin No 69 Palu, Provinsi Sulawesi Tengah. Adapun alasan mengambil lokasi di Bank BNI Syariah cabang Palu ini karena merupakan salah satu Bank umum Syariah

\footnotetext{
${ }^{35}$ Sugiyono, Metode Penelitian Pendidikan Pendekatan Kuantitatif, Kualitatif, dan R\&D, (Cet. XX; Bandung: Alfabeta, 2014), hal.14

${ }^{36}$ Nurdin, N. (2017b). To Research Online or Not to Research Online: Using Internet-Based Research in Islamic Studies Context. Indonesian Journal of Islam and Muslim Societies, 7(1), 31-54.

${ }^{37}$ Nurdin, N. (2017a). Research in Online Space: The Use of Social Media for Research Setting Jurnal Sistem Informasi (Journal of Information System), 13(1), 67-77.
}

yang paling akhir berdiri jika dibandingkan dengan Bank umum Syariah lainnya.

Dalam penelitian ini sampel diambil dari sebagian populasi yang telah ditentukan, yaitu jumlah penabung pada produk tabungan iB Baitullah Hasanah di Bank BNI Syariah cabang Palu. Jumlah penabung tabungan iB Baitullah Hasanah yang menjadi sampel penelitian ini adalah 99 orang.

Data dikumpul melalui survey yang dibagikan kepada jumlah sampel tersebut. Survey menggunakan skala Likert 5. Hasil penelitian kemudian di olah dengan menggunakan SPSS ${ }^{38}$. Hasil survey terlebih dahulu dilakukan uji validitas dan reliabilitas sebelum dilakukan uji f.

\section{HASIL DAN PEMBAHASAN}

\subsection{Demografi Respondent}

Penelitian ini dilakukan pada Nasaabah penabung pada Bank BNI Syariah cabang Palu. Data penelitian menggunakan instrument kuesioner yang dibagikan kepada Masyarakat atau Nasabah Bank BNI Syariah cabang Palu sebagai sampel penelitian. Penyebaran kuesioner disebarkan oleh

38 Nurdin, N., Pettalongi, S. S., \& Mangasing, M. (2019, 26-27 Sept. 2019). Understanding Digital Skill Use from The Technology Continuance Theory (TCT). Paper presented at the 2019 6th International Conference on Information Technology, Computer and Electrical Engineering (ICITACEE). 
peneliti kepada sampel yang diteliti dengan perincian seperti dalam tabel berikut ini.

Tabel 1. Responden Berdasarkan Jenis Kelamin

\begin{tabular}{|c|c|c|}
\hline Jenis Kelamin & Responden & $\begin{array}{c}\text { Presentase } \\
(\%)\end{array}$ \\
\hline Laki-laki & 55 & $55,6 \%$ \\
\hline Perempuan & 44 & $44,4 \%$ \\
\hline Jumlah & $\mathbf{9 9}$ & $\mathbf{1 0 0 \%}$ \\
\hline
\end{tabular}

Pada tabel 1 diatas menunjukan bahwa dari 99 orang sampel dalam penelitian ini yang berjenis kelamin laki-laki berjumlah 55 orang $(55,6 \%)$ dan yang berjenis kelamin perempuan 44 orang $(44,4$ $\%)$ sehingga nampak disini bahwa sebagian besar sampel penelitian ini berjenis kelamin laki-laki.

Tabel 2. Responden Menurut Pendidikan

\begin{tabular}{|c|c|c|}
\hline $\begin{array}{c}\text { Pendidikan } \\
\text { Terakhir }\end{array}$ & Responden & $\begin{array}{c}\text { Persentase } \\
\text { (\%) }\end{array}$ \\
\hline SD & 3 & $3,0 \%$ \\
\hline SMP & 3 & $3,0 \%$ \\
\hline SMA & 25 & $25,3 \%$ \\
\hline D3 & 12 & $12,1 \%$ \\
\hline S1 & 50 & $50.6 \%$ \\
\hline S2/S3 & 6 & $6,0 \%$ \\
\hline Total & 99 & $100 \%$ \\
\hline
\end{tabular}

Pada tabel 2 diatas menunjukkan bahwa responden yang yang memiliki presentase paling tinggi adalah responden yang memiliki pendidikan terakhir S1 dengan jumlah presentase sebesar $50.6 \%$. Sedangkan responden yang memiliki presentase terendah adalah responden yang memiliki pendidikan terakhir SD dam SMP yang memiliki presentase $3,0 \%$. Hal ini menunjukkan bahwa responden yang memiliki pendidikan terakhir S1 lebih banyak memilih produk tabungan iB Baitullah Hasanah pada Bank BNI Syariah cabang Palu.

\subsection{Uji Validitas dan Reliabilitas}

Dengan menggunakan instrumen yang valid dan realibel dalam pengumpulan data, maka diharapkan hasil penelitian akan menjadi valid dan realibel. Jadi instrumen valid dan realibel merupakan syarat mutlak untuk mendapatkan hasil penelitian yang valid dan realibel. Hal ini tidak berarti bahwa dengan menggunakan instrumen yang telah teruji validitas dan realibitasnya, otomatis hasil (data) penelitian menjadi valid dan realibel. Hal ini masih akan di pengaruhi oleh kondisi objek yang di teliti, dan kemapuan orang yang menggunakan instrumen untuk mengumpulkan data.

Instrumen yang dinyatakan valid dan realibel adalah; instrumen yang valid, berarti alat ukur yang digunakan untuk mendapatkan data (mengukur) itu valid. Valid berarti instrumen tersebut dapat digunakan untuk mengukur apa yangseharusnya diukur. Sedangkan instrumen yang realibel berarti bila digunakan untuk mengukur berkali-kali akan menghasilkan data yang sama.

Uji validitas yaitu mengkorelasikan masing-masing pernyataan dengan jumlah skor untuk masing-masing variabel. Syarat 
minimum untuk memenuhi syarat adalah apabila $r=0,3$ jadi apabila korelasi antar butir dengan skor total kurang dari 0,3 maka instrumen tersebut tidak valid. ${ }^{39}$

Tabel 3. Uji Validitas

\begin{tabular}{|c|c|c|c|c|}
\hline Variabel & Pernyataan & $\begin{array}{c}\text { Corrected Item } \\
\text { Total } \\
\text { Correlation }\end{array}$ & R Kritis & Keterangan \\
\hline \multirow{4}{*}{ Produk (X1) } & 1 & 0.474 & 0.3 & Valid \\
\hline & 2 & 0.693 & 0.3 & Valid \\
\hline & 3 & 0.656 & 0.3 & Valid \\
\hline & 4 & 0.574 & 0.3 & Valid \\
\hline \multirow{4}{*}{ Promosi (X2) } & 1 & 0.356 & 0.3 & Valid \\
\hline & 2 & 0.478 & 0.3 & Valid \\
\hline & 3 & 0.687 & 0.3 & Valid \\
\hline & 4 & 0.319 & 0.3 & Valid \\
\hline \multirow{4}{*}{ Harga (X3) } & 1 & 0.324 & 0.3 & Valid \\
\hline & 2 & 0.572 & 0.3 & Valid \\
\hline & 3 & 0.691 & 0.3 & Valid \\
\hline & 4 & 0.350 & 0.3 & Valid \\
\hline \multirow{4}{*}{$\begin{array}{l}\text { Minat } \\
(\mathrm{Y})\end{array}$} & 1 & 0.496 & 0.3 & Valid \\
\hline & 2 & 0.657 & 0.3 & Valid \\
\hline & 3 & 0.647 & 0.3 & Valid \\
\hline & 4 & 0.588 & 0.3 & Valid \\
\hline
\end{tabular}

Dari tabel diatas, terlihat bahwa nilai rhitung pada kolom Corrected Item TotalCorrelationuntuk masing-masing item memiliki rhitung lebih besar dan positif dari 0,3 yang artinya masing-masing item pertanyaan dalam variabel $\mathrm{X} 1, \mathrm{X} 2$,X3dan $\mathrm{Y}$ adalah valid semua.

Setelah instrumen dalam penelitian ini dinyatakan valid, maka selanjutnya perlu dilakukan uji reliabilitas atau uji keandalan instrumen penelitian. Pengujian reliabilitas dilakukan dengan internal consistensy atau derajat ketepatan jawaban. Untuk penelitian ini digunakan Statistical Packaged For social Sciences (SPSS) sebagai alternatif pengujian reliabilitas untuk mengetahui konsistensi hasil sebuah jawaban tentang tanggapan responden. Untuk melakukan pengujian reliabititas penulis menggunakan SPSS versi 16, yaitu dalam mengukur reliabilitas disini menggunakan uji statistik Cronbach Alpha $(\alpha)$, yang mana satu variabel dikatakan reliabel jika memiliki Cronbach Alpha lebih dari 0,60 (>0,60). ${ }^{40}$

Hasil pengujian reliabilitas instrumen menggunakan alat bantu oleh statistik SPSS versi 16.0for windowsdapat diketahui dalam tabel berikut:

Tabel 4. Uji Reliabilitas

\begin{tabular}{|c|c|c|c|}
\hline Variabel & $\begin{array}{c}\text { Reliability } \\
\text { Coeficiens }\end{array}$ & $\begin{array}{c}\text { Cronbach } \\
\text { alpha }\end{array}$ & Keterangan \\
\hline produk (X1) & 4 Item & 0,783 & Realibel \\
\hline Promosi (X2) & 4 Item & 0,661 & Realibel \\
\hline Harga (X3) & 4 Item & 0,686 & Realibel \\
\hline Minat (Y) & 4 Item & 0,781 & Realibel \\
\hline
\end{tabular}

Sumber data: Output SPSS 16,0

Dari tabel 4 di atas dapat diketahui bahwa masing-masing variabel memiliki Cronbach Alpha lebih dari 0,60 $(\alpha>0,60)$, yang artinya bahwa semua variabel yaitu $\mathrm{X} 1, \mathrm{X} 2, \mathrm{X} 3$ dan $\mathrm{Y}$ adalah realibel. Dapat disimpulkan bahwa instrumen penelitian 
menunjukkan nilai konsistensi yang tinggi sehingga dinilai relibel dalam fungsi ukururannya. Berarti instrumen penelitian dalam fungsi ukurnya memiliki reliabilitas yang tinggi untuk menghasilkan konsistensi pengukuran bila digunakan berulang kali dalam pengumpulan data. Dengan demikian pengolahan data dapat dilanjutkan ke jenjang selanjutnya.

\subsection{Pengujian Hipotesis}

Uji simultan digunakan untuk menguji apakah variabel independen (X) benar-benar memberikan kontribusi terhadap variabel (Y). Dalam pengujian ini ingin diketahui apakan variabel independen (X) secara bersama-sama meberikan kontribusi secara signifikan terhadap variabel dependen (Y).

Tabel 5. Uji Simultan

\begin{tabular}{|c|c|c|c|c|c|c|}
\hline \multicolumn{7}{|c|}{ ANOVA $^{b}$} \\
\hline \multicolumn{2}{|c|}{ Model } & $\begin{array}{l}\text { Sum of } \\
\text { Squares }\end{array}$ & Df & $\begin{array}{l}\text { Mean } \\
\text { Square }\end{array}$ & $\mathrm{F}$ & Sig. \\
\hline \multirow[t]{3}{*}{1} & Regression & 122.675 & 3 & 40.892 & 8.566 & $.000^{\mathrm{a}}$ \\
\hline & Residual & 453.507 & 95 & 4.774 & & \\
\hline & Total & 576.182 & 98 & & & \\
\hline \multicolumn{5}{|c|}{$\begin{array}{l}\text { a. Predictors: (Constant), harga(X3), produk(X1), } \\
\text { promosi }(\mathrm{X} 2)\end{array}$} & & \\
\hline \multicolumn{4}{|c|}{ b. Dependent Variable: $\operatorname{minat}(\mathrm{Y})$} & & & \\
\hline
\end{tabular}

Berdasarkan hasil uji ANOVA (Analysis of Varians) atau $\mathrm{F}$ test diketahui nilai signifikansi untuk pengaruh produk, harga dan promosi secara simultan terhadap minat sebesar $0.000<0.05$ dan nilai $F_{\text {hitung }}$ 8.566> $F_{\text {tabel }} 2.70$, sehingga dapat disimpulkan bahwa H3 diterima yang berarti terdapat pengaruh produk(X1) promosi(X2) dan harga(X3) secara simultan terhadap $\operatorname{minat}(\mathrm{Y})$.

Uji parsial digunakan untuk menguji apakah sebuah variabel independen (X) benar-benar memberikan kontribusi terhadap variabel dependen (Y). Dalam pengujian ini, ingin diketahui apakah jika secara terpisah, masing-masing variabel independen (X) masih memberikan kontribusi secara signifikan terhadap variabel dependen (Y).

Tabel 6. Uji Parsial

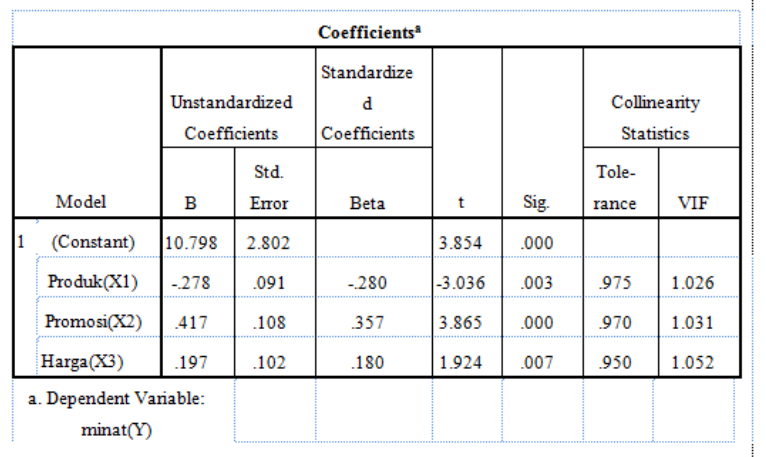

Berdasarkan hasil perhitungan statistik uji t dari 3 variabel bebas yang dimasukkan dalam model regresi terlihat bahwa:

1.

iketahui nilai Sig. untuk pengaruh produk (X1) terhadap minat (Y) adalah sebesar $0.000<0.05$ dan nilai $t_{\text {hitung }}-3.036<\mathrm{t}_{\text {tabel }}$ 1.665, sehingga dapat disimpulkan bahwa $\mathrm{H} 1$ tidak terdapat pengaruh produk (X1) terhadap minat (Y). 
2.

iketahui nilai Sig. untuk pengaruh promosi (X2) terhadap minat (Y) adalah sebesar $0.001<0.05$ dan nilai thitung 3.865> $\mathrm{t}_{\text {tabel }} 1.665$, sehingga dapat disimpulkan bahwa $\mathrm{H} 2$ diterima yang berarti terdapat pengaruh promosi(X2) terhadap minat (Y).

3.

iketahui nilai Sig. untuk pengaruh harga (X3) terhadap minat (Y) adalah sebesar $0.001<0.05$ dan nilai $t_{\text {hitung }} 1.924>\mathrm{t}_{\text {tabel }}$ 1.665, sehingga dapat disimpulkan bahwa H3 diterima yang berarti terdapat pengaruh harga $(\mathrm{X} 3)$ terhadap minat $(\mathrm{Y})$.

\subsection{Pembahasan}

\section{Pengaruh Produk Terhadap Minat}

Produk merupakan keseluruhan gabungan karakteristik produk yang dihasilkan dari pemasaran, rekayasa, produksi, dan pemeliharaan yang membuat produk tersebut dapat digunakan memnuhi harapan pelanggan atau konsumen.

Berdasarkan hasil pengujian dapat diketahui dari tabel Coefficients variabel produk (X1) berpengaruh negatifterhadap minat (Y). Dengan nilai signifikan 0.000> 0.05.Maka dari pembahasan ini menunjukkan bahwa variabel produk tidak mempengaruhi minat nasabah.

2. Pengaruh Promosi
Promosi adalah aru§ insformasi atau persuasi satu arah yang dibuat untuk mengarahkan seseorang atau orgaisasi kepada tindakan yang menciptakan pertukaran dalam pemasaran. Untuk mencapai target, maka harus lebih fokus perhatian dalam berkomunikasi dengan calon nasabah melalui produk yang disampaikan. Promosi juga menjadi salah satu faktor penentu keberhasilan suatu program pemasaran. Seberapa bagus kualitas produk yang disampaikan apabila nasabah tidak perna mendengar atau yakin akan produk itu maka mereka tidak akan berminat.

Tujuan utamanya adalah mengenalkan kegiatan usahanya kepada masyarakat, semakin gencar usahanya melakukan promosi semakin kuat pula image usaha yang dipromosikan, karena pada dasarnya promosi menunjukan segala kelebihan yang dimiliki.

Berdasarkan hasil pengujian dapat diketahui dari tabel coefficient variabel promosi (X2) berpengaruh positif dan signifikan terhadap minat (Y) . Dengan nilai signifikan $0.001<0.05$. Maka dari pembahasan ini menunjukkan bahwa variabel promosi mempengaruhi minat nasabah.

3. Pengaruh Harga Terhadap Minat

Terhadap Minat 
Harga merupakan sejumlah nilai yang ditukarkan konsumen dengan manfaat dari memiliki atau menggunakan produk atau jasa yang nilainya ditetapkan oleh pembeli atau penjual melalui tawar menawar atau ditetapkan oleh penjual untuk satu harga yang sama terhadap semua pembeli.

Harga salah satu aspek penting dalam kegiatan marketing mix. Penentuan harga menjadi sangat penting untuk diperhatikan, mengingat harga sangat menentukan laku tidaknya produk. Salah menentukan harga akan berakibat fatal terhadap produk yang ditawarkan.

Berdasarkan hasil pengujian dapat diketahui dari tabel coefficient variabel harga (X3) berpengaruh positif dan signifikan1. terhadap minat $(\mathrm{Y})$. Dengan nilai signifikan $0.001<0.05$. Maka dari pembahasan ini menunjukkan bahwa variabel harga mempengaruhi minat nasabah.

4.

Pengaruh

Produk,Promosi dan Harga terhadap Minat

Ketiga variabel independen yaitu produk,promosi dan harga berpengaruh positif namun tidak berpengaruh secara langsung.

Dari hasil pengujian serentak pada kedua variabel independen yaitu produk (X1),promosi (X2)dan harga (X3) terhadap variabel dependen yaitu minat (Y), maka hasilnyamenunjukkan bahwa ketiga variabel secara serentak memberikan pengaruh positif dan signifikan terhadap minat nasabah. Hal ini dapat dilihat dari hasil uji tabel ANOVA, besar nilai Sig. yaitu $0.000<0.05$ yang artinya kedua variabel independen tersebut berpengaruh positif secara bersama-sama dan signifikan terhadap minat nasabah memilih produk tabungan iB Baitullah hasanah cabang Palu.

\section{KESIMPULAN}

Berdasarkan hasil penelitian dan analisis data yang telah diuraikan pada bagian empat di atas, maka dapat diambil kesimpulan hasilpenelitian sebagai berikut:

Produk tidak berpengaruh terhadap minat, promosi terdapat pengaruh positif dan signifikan terhadap minat dan Harga berpengaruh positif dan signifikan terhadap minat. Dengan uraian sebagai berikut :

a. Produk tidak berpengaruh terhadap minat nasabah. Hasil penelitian ini sejalan yang dilakukan oleh Risky Amalia Bachriansyah. Bahwa produk tidak selalu jadi patokan dalam menentukan minat nasabah. Hal ini dapat dilihat dari penelitian yang telah diteliti oleh peneliti menunjukkan bahwa dari hasil uji $\mathrm{t}$ diperoleh nilai $t_{\text {hitung }}>t_{\text {tabel }}$ yaitu $3.036<\mathrm{t}_{\text {tabel }} 1.665$ dengan nilai probabilitas sebesar 0.000 berarti lebih kecil dari 0.05 maka H1 ditolak. Yang artinya 
produktidak berpengaruh terhadap minat nasabah memilih produk tabungan iB Baitullah Hasanah pada Bank BNI Syariah cabang Palu.

b. Promosi berpengaruh positif dan signifikan terhadap minat nasabah. Hasil penelitian ini sejalan yang dilakukan oleh Erni Damayanti, bahwa promosi adalah sebagai sarana untuk memperkenalkan dan menentukan minat nasabah. Hal ini dapat dilihat dari penelitian yang telah diteliti oleh peneliti menunjukkan bahwa dari hasil uji $t$ diperoleh nilai $t_{\text {hitung }}>t_{\text {tabel }}$ yaitu 3.865> tabel 1.665 dengan nilai probabilitas sebesar 0.001 berarti lebih kecil dari 0.05 maka $\mathrm{H} 2$ diterima. Yang artinya promosi berpengaruh positif signifikan terhadap minat nasabah memilih produk tabungan iB Baitullah Hasanah pada Bank BNI Syariah cabang Palu.

c. Harga berpengaruh positif dan signifikan terhadap minat nasabah. Hasil penelitian ini sejalan dengan Weli Ofni putri, bahwa harga sangat menjadi salah satu pertimbangan nasabah untuk memilih. Hal ini dapat dilihat dari penelitian yang telah diteliti oleh peneliti menunjukkan bahwa dari hasil uji $\mathrm{t}$ diperoleh nilai $t_{\text {hitung }}>t_{\text {tabel }}$ yaitu 1.924> $t_{\text {tabel }} 1.665$ dengan nilai probabilitas sebesar 0.001 berarti lebih kecil dari 0.05 maka H3 diterima. Yang artinya harga berpengaruh positif signifikan terhadap minat nasabah memilih produk tabungan iB Baitullah Hasanah pada Bank BNI Syariah cabang Palu.

2. Produk, promosi dan harga berpengaruh simultan dan signifikan terhadapminat nasabah memilih produk tabungan iB Baitullah Hasanah pada Bank BNI Syariah cabang Palu. Hal ini dapat dilihat dari penelitian yang telah diteliti oleh peneliti menunjukkan bahwa dari hasil uji $F$ diperoleh nilai $F_{\text {hitung }}>F_{\text {tabel }}$ yaitu 8.566> $F_{\text {tabel }}$ 3.09dengan nilai probabilitas sebesar 0.000 berarti lebih kecil dari 0.05 maka H4 diterima. Yang artinya produk, promosi dam harga berpengaruh secara simultan dan signifikanterhadap minat nasabah memilih produk tabungan iB Baitullah Hasanah pada Bank BNI Syariah cabang Palu

\section{Daftar Pustaka}

Abdullah,Thamrin. Manajemen Pemasaran Jakarta : PT RajaGrafindoPersada, 2003.

Adrian,Payne. The Essence of Serfice Marketing, Yogyakarta: Andi offset, 1993.

. Service Marketing Pemasaran Jasa. Yogyakarta, 2006 Algifari, Analisis Regresi,Yogyakarta:BPEFUGM,2000

Amrin. Abdullah, Strategi Pemasaran Asuransi Syariah, Jakarta: Grasindo, 2007. Assauri Sofjan, Manajemen Pemasaran Jakarta PT.Raja Grafindo Persada, 2007

Bahtiar. Latief M. "pengaruh strategi bauran pemasaran terhadap minat 
berkunjung kembali di objek wisata pantai kabupaten gunung kidul'2016 (http://eu.dspmulti.com). Diakses pada tanggal 15 maret 2019

Dahlan. Ahmad, Bank Syariah Teoritik, Praktik, Kritik, Jakarta: Teras, 2012.

Departemen Agama RI, Al-Quran dan Terjemahannya, Bandung: PT syamil cipta media, 2010.

Fitriani.Laila, "Pengaruh Strategi Pemasaran Terhadap Minat Nasabah Memilh Produk

Tabunganku(diba

nk muammalat

Ghozali. Imam, Aplikasi Analisis Muktivariate, dengan Program IBM SPSS 21, Edisi ketujuh, Semarang: Badan Penerbit Universitas Diponegoro, 2013.http://jurnalsdm.blogspot.co.id/2009/04/peranpositioning-dalam-strategi.html? $\mathrm{m}=1$, diakses pada 15 Maret 2019.

Ikatan Bankir Indonesia, Strategi Bisnis Bank Syariah, Jakarta: PT. Gramedia Pustaka Utama, 2015.

J.Stanton. William, Prinsip Pemasaran, Edisi VII, Jakarta: Erlangga, 1996. Kasmir, Pemasaran Bank, Jakarata: kencana 2008.

Kamsir, kewirausahaan, Jakarta: PT Raja Grafindo. 2006. Kertajaya. Hermawan, dan Sula M.syakir, syariah, 2003

Kotler. Philip, Manajemen Pemasaran, Edisi XIII, Jakarta: Erlangga, 2009.

Kotler. Philip, manajemen pemasaran (Jakarta:PT Prenhalindo,2008)

Latan. Hengky, Aplikasi Analisis Data Statistik Untuk Ilmu Sosial Sains dengan IBM SPSS, Bandung: Alfabeta, 2014.

Martono. Nanang, Metode Penelitan Kuantitatif Analisis Isi dan Analisis Data Sekunder, Cet. IV; Jakarta: PT. Grafindo Persada, 2016.

Mohamad .Muhtar, "pengaruh strategi pemasaran terhadap keputusan pembelian mobi mitsubishi pajero di kota makassar, (makasar,2017) (http://erasupra.wordpres.com).

Diakses 15 Maret 2019

Mursid M., Manajemen Pemasaran Jakarta: Bumi Aksara,2014

Nurdin, N., Pettalongi, S. S., \& Mangasing, M. (2019, 26-27 Sept. 2019). Understanding Digital Skill Use from The Technology Continuance Theory (TCT). Paper presented at the 2019 6th International Conference on Information Technology, Computer and Electrical Engineering (ICITACEE).

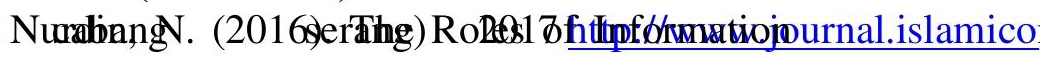
Technology in Islamic Bank Knowledge Management: A study of Two Syariah Banks in Palu. Hunafa: Jurnal Studia Islamika, 13(2), 181217. doi: https://doi.org/10.24239/jsi.v13i2.444. 181-217

Perwataatmadja. Karnaen, Antonio M.Syafi'i, Apa dan Bagaimana Bank Islam, Yogyakarta: Dana Bhakhti Wakaf, 1992.

Rahmawati. Siti. "Pengaruh Trend Fashion Terhadap Keputusan Membeli Busana Muslim Di Kalangan Mahasiswa Institut Agama Islam Negeri Palu." (Skripsi: tidak diterbitkan2017).

Rangkuti. Freddy, Analisis swot: tekhnik membedah kasus bisnis Jakarta: Gramedia pustaka umum, 2006.

Ridwan, Penelitian untuk Guru, Karyawan dan Peneliti, Bandung: Alfabeta, 2012.

Sarjono. Haryadi \& Julianti Winda, SPSS vs Lisrel Sebuah Pengantar, Aplikasi Untuk Riset, Jakarta: Salemba Empat, 2011.

Sugiyono, Metode Penelitian Pendidikan Pendekatan Kuantitatif, Kualitatif, dan $R \& D$, Cet. XX; Bandung: Alfabeta, 2014.

Sujarweni V. Wiratna, Metode Penelitian Lengkap, Praktis, dan Mudah Dipahami, Cet. I; Yogyakarta: Pustakabarupress,2014. 
Sujianto. Eko Agus, Aplikasi Statistik Jurnal Manajemen Vol.1 No 4 dengan SPSS 16.0, Jakarta: PT. Prestasi Pustaka, 2009.

(Desember,2017) hal 23

Sunyoto. Danang, Analisis Regresi dan Uji Hipotesis, Yogyakarta: CAPS, 2011. Taniredja.Takiran \& Mustfida Hidayat, Penilitian Kuantitatif, Purwekerto: alfabeta, 2013.

Wowor. Ronald. Valdy, Bauran Pemasaran

Jasa Pengaruhnya Terhadap
Kepuasan Konsumen Pengguna
Avanza PT.Hasjrat Abadi Manado"

